\title{
PENGARUH BLENDED LEARNING BERBANTUKAN GOOGLE CLASSROOM TERHADAP KETERAMPILAN BERPIKIR KREATIF DAN KEMANDIRIAN BELAJAR PESERTA DIDIK
}

\author{
Nukhbatul Bidayati Haka, Liza Anggita Ellyandhani, Bambang Sri Anggoro, dan \\ Abdul Hamid
}

Universitas Islam Negeri Raden Intan Lampung

e-mail: nukhbatulbidayatihaka@radenintan.ac.id

\begin{abstract}
Abstrak
Tujuan penelitian ini adalah untuk mengetahui pengaruh pembelajaran blended learning berbantukan google classroom terhadap kemampuan berpikir kreatif dan kemandirian belajar peserta didik. Penelitian ini menggunakan pendekatan kuantitatif dengan desain kuasi eksperimen. Instrumen pengumpulan data menggunakan tes esai dengan 15 soal dan angket sebanyak 20 pertanyaan. Teknik pengambilan sampel penelitian ini dilakukan dengan cara cluster random sampling. Uji hipotesis menggunakan independent $t$-test. Hasil penelitian menunjukkan bahwa terdapat pengaruh pembelajaran blended learning berbantukan google classroom terhadap kemampuan berpikir kreatif dan kemandirian belajar peserta didik.
\end{abstract}

Keywords: Kemampuan Berpikir Kreatif, Kemandirian Belajar, Blended Learning, Google Classroom

\section{Abstract}

Research purposes is knowing the effect of Google Learning Blended Learning with classroom assistance on the ability to think creatively and students' learning independence. This research uses a quantitative approach with a quasi-experimental design. Data collection instruments using essay tests with 15 questions and a questionnaire of 20 questions. The sampling technique of this study was conducted by cluster random sampling. Hypothesis testing uses independent $t$-test. The results showed that there was an influence of google classroom blended learning on the ability to think creatively and student learning independence.

Keywords: The Perfection of Creative Thinking, Self-Reliance Learning, Blended Learning, Google Clasroom

\section{PENDAHULUAN}

Era digital global saat ini penuh peluang dan tantangan sains untuk melakukan aktivitas kehidupan sehari-hari (Arnyana, 2019). Sains memiliki kontribusi yang cukup besar dalam perkembangan teknologi (Damanhuri et al., 2013). Peserta didik masa depan harus kritis, kreatif, kompetitif, dan untuk memecahkan masalah (Listiana, 2013).

Tuntutan global menuntut dunia pendidikan untuk selalu dan senantiasa menyesuaikan perkembangan teknologi (Denizulaiha, 2018; Santono, 2019) dalam 
peningkatan mutu pendidikan, terutama penyesuaian penggunaan teknologi informasi dan komunikasi bagi dunia pendidikan khususnya dalam proses pembelajaran (Priana, 2017; Weni \& Isnani, 2016).

Proses pembelajaran harus membuat peserta didik bersemangat mengikuti pembelajaran. (Syarif et al., 2016), sehingga mereka bisa mengikuti kegiatan pembelajaran secara berkesinambungan (Juniati \& Widiana, 2017). Untuk mencapai kecakapan gobal dalam hal cara berpikir, penguasaan teknologi, dan sebagai warga dunia maka diperlukan pendidikan yang menekankan pembelajaran untuk mengetahui potensi peserta didik ( Imawanty \& Fransiska, 2019; Ramdhani, 2017; Sudarsana, 2016). Belajar ialah proses memperoleh ilmu dan mengubah tingkah laku seseorang (Kurniasih \& Haka, 2017).

Teknologi dapat meningkatkan kualitas bila diterapkan secara bijak untuk pendidikan dan latihan dan mempunyai arti yang sangat penting bagi kesejahteraan (Karyawati, 2012; Suryadi, 2015). Dengan adanya perkembangan teknologi dan informasi dalam dunia pendidikan maka pada saat itu sudah dimungkinkan untuk diadakan belajar jarak jauh dengan menggunakan media internet (Budiman, 2017; Rodiawati \& Komarudin, 2018).

Perubahan tuntutan dalam pembelajaran yang menjadikan dunia pendidikan memerlukan inovasi dan kreativitas dalam proses pembelajaran (Nurjanah, 2015). Pembelajaran memegang peranan yang sangat penting dalam kehidupan karena pembelajaran merupakan proses perubahan sikap dan tingkah laku seseorang.(Guswiyata et al., 2018). Pembelajaran bukanlah sekedar membuat peserta didik menjadi sopan, taat, jujur, hormat, setia, sosial, dan sebagainya. Selain itu juga, pembelajaran tidak juga bermaksud hanya membuat mereka tahu ilmu pengetahuan, teknologi, dan seni serta mampu mengembangkannya (Anggoro, 2015b) melainkan diperlukan pemberdayaan keterampilan berpikir kreatif dan kemandirian belajar peserta didik.

Kemampuan berpikir kreatif sangat penting sebagai bagian dari kecakapan hidup (Anggoro, 2015a) yang menjadi salah satu dari tujuan pendidikan nasional (Sudarsana, 2016). Kemampuan berpikir kreatif sangat penting dimiliki oleh setiap individu, terlebih di era ekonomi global berbasis pengetahuan dan juga teknologi (Riyadi et al., n.d.). Guna mengoptimalkan kemampuan berfikir kreatif, peserta didik harus memiliki kemandirian dalam belajar. Kemandirian belajar adalah kemampuan seseorang dalam mengatur semua aktivitas pribadi, kompetensi, dan kecakapan secara mandiri berbekal kemampuan dasar yang dimiliki individu tersebut, khususnya dalam proses pembelajaran (Mayasari, 2016).

Hasil pra survei yang telah dilakukan di SMA Al Azhar 3 Bandar Lampung, adalah rendahnya kemampuan berpikir kreatif dan kemandirian belajar pada materi pokok biologi, terutama persoalan dan pekerjaan yang ditugaskan guru, serta tidak tepatnya metode 
pembelajaran yang diterapkan oleh guru. Hasil wawancara menunjukkan bahwa kegiatan dalam kelas masih berpusat pada guru atau satu arah, dalam satu kelas hanya beberapa anak saya yang mendapat nilai di atas 70 , dan dalam menjawab soal pesera didik tidak lancar.

Karakteristik dari materi pembelajaran sistem sirkulasi yaitu secara umum sistem sirkulasi darah didalam tubuh manusia dapat dibagi menjadi dua bagian yaitu sistem sirkulasi umum (sistemik) dimana sirkulasi darah yang mengalir dari jantung kiri keseluruh tubuh dan kembali ke jantung kanan. Dan yang kedua yaitu sistem sirkulasi paru (pulmoner) dimana darah yang mengalir dari jantung kanan ke paru-paru lalu kembali ke jantung kiri. Materi sistem sirkulasi tidak selesai jika dipelajari dengan buku cetak saja, pendidik harus menyajikan media alternatif lain seperti video mengenai skema sistem sirkulasi agar peserta didik lebih memahami materi sistem sirkulasi. Akan tetapi, selama ini pembelajaran materi sistem sirkulasi dilakukan dengan cara menggunakan buku cetak saja, 30\% peserta didik tidak lulus KKM. Bahan ajar yang dipakai hanya buku cetak saja belum mempertimbangkan blended learning sebagai salah satu alternatif model pembelajaran yang diterapkan dalam kelas.

Model Blended Learning memiliki kelebihan yaitu sangat potensial sebagai sumber belajar bagi pembelajar yang tidak memiliki cukup waktu untuk belajar dan juga memfasilitasi bahan belajar tambahan yang dipakai agar bisa mempermudah pemahaman materi pembelajaran. Hasil penelitian Setyoko (2018b) menunjukkan bahwa terdapat pengaruh yang signifikan model blended learning berbantukan google classroom terhadap peningkatan hasil belajar mahapeserta didik pendidikan fisika. Hal yang senada dengan hasil penelitian Mayasari, (2016) menunjukkan tedapat peningkatan kemandirian belajar peserta didik kelas $X$ Akutansi 3 pada mata pelajaran pengantar aktuansi dan keuangan salah satu SMK di Surakarta.

Model blended learning dapat digunakan sebagai salah satu variasi dalam pembelajaran karena dengan menggunakan strategi pembelajaran ini mahapeserta didik dapat berpartisipasi aktif dalam pembelajaran dan juga mampu meningkatkan kemampuan berpikir kreatif. Model blended learning dipandu dengan media google classroom yang memiliki kelebihan yaitu membantu pendidik agar tidak membuang waktu dan kelas tetap terkendali, serta menigkatnya interaksi. Jadi dari permasalahan tersebut, peneliti tertarik menerapkan model blended learning berbantukan google classroom untuk meningkatkan keterampilan berpikir kreatif dan kemandirian belajar peserta didik.

\section{METODE}

Penelitian dilakukan pada Kelas XI Semester Ganjil di SMA Al Azhar 3 Bandar Lampung. Metode yang pakai ialah kuantitatif data berupa teknik stataistik. Memakai 
metode kuasi eksperimen. Desain penelitian yaitu pretes dan postes dengan dua kelas. Kelas eksperimen ialah kelas XI IPA 3 menggunakan model pembelajaran blended learning dan XI IPA 5 sebagai kelas kontrol model pembelajaran direct instruction.

Populasi terdapat 5 kelas (XI IPA 1-XI IPA 5) masing-masing kelas berjumlah 29 peserta didik. Teknik pengambilan sampel pada penelitian ini dengan cara teknik acak kelas dan didapatkan sampel yakni diambil dari $25 \%$ dari semua peserta didik kelas XI IPA di SMA Al-Azhar 3. Peneliti menggunakan teknik pengumpulan data berupa tes yang diberikan berupa test essay dan angket penilaian sikap berbentuk daftar cek (checklist).

Tes kemampuan berpikir kreatif yang telah diuji cobakan dari 15 item soal didapatkan 10 soal yang valid yaitu soal nomor 2, 7, 9, 11, 15. Angket kemandirian belajar yang terdiri dari 20 item soal dan keseluruhan item valid. Untuk perincian hasil perhitungan validitas dapat dilihat dilampiran. 15 item soal untuk tes kemampuan berpikir kreatif didapatkan nilai reliabilitas sebesar 0,77 termasuk dalam kriteria tinggi. Untuk angket kemandirian belajar didapatkan nilai reliabilitas sebesar 0,79 termasuk dalam kriteria tinggi. Tes kemampuan berpikir kreatif ini diberikan dalam bentuk essay dengan sistem Grading (4-0). Uji hipotesis pada penelitian ini diuji menggunakan uji t.

\section{HASIL DAN PEMBAHASAN}

Hasil penelitian menunjukkan bahwa pembelajaran dengan menggunakan google classroom sangat efesien terutama bagi peserta didik dapat dilihat dari antusiasnya peserta didik menjawab pertanyaan dalam google classroom dan saling tanya dengan peserta didik lainnya. Adapun rekapitulasi hasil tes kemampuan berpikir kreatif peserta didik dapat dilihat pada Tabel 1.

\begin{tabular}{lccccc} 
Tabel 1. Rekapitulasi Rata-rata Nilai N-Gain Kemampuan Berpikir Kreatif \\
Kelas Eksperimen dan Kelas Kontrol \\
\hline \multicolumn{7}{c}{$\begin{array}{l}\text { Jumlah } \\
\text { Peserta } \\
\text { Didik }\end{array}$} & $\begin{array}{c}\text { Nilai Rata-Rata } \\
\text { Pretest }\end{array}$ & Posttest & N-Gain & Kriteria \\
& 29 & 50,00 & 79,08 & 0,59 & \\
\hline Eksperimen & 29 & 48,53 & 69,62 & 0,40 & Sedang \\
Kontrol & & &
\end{tabular}

Tabel 1 menunjukan perolehan nilai rata-rata pretest kelas eksperimen sebesar 50,00 , sedangkan nilai rata-rata posttest sebesar 79,08 dengan nilai N-Gain 0,59 termasuk kedalam kategori sedang. Sedangkan pada kelas kontrol perolehan nilai ratarata pretest sebesar 48,53 dan nilai rata-rata posttest sebesar 69,62 nilai N-Gain sebesar 0,40 yang termasuk kedalam kategori sedang. Untuk melihat peningkatan nilai kemampuan berpikir kreatif dapat dilihat pada analisis per indikator kemampuan berpikir kreatif pada kelas eksperimen dan kontrol seperti pada Gambar 1. 


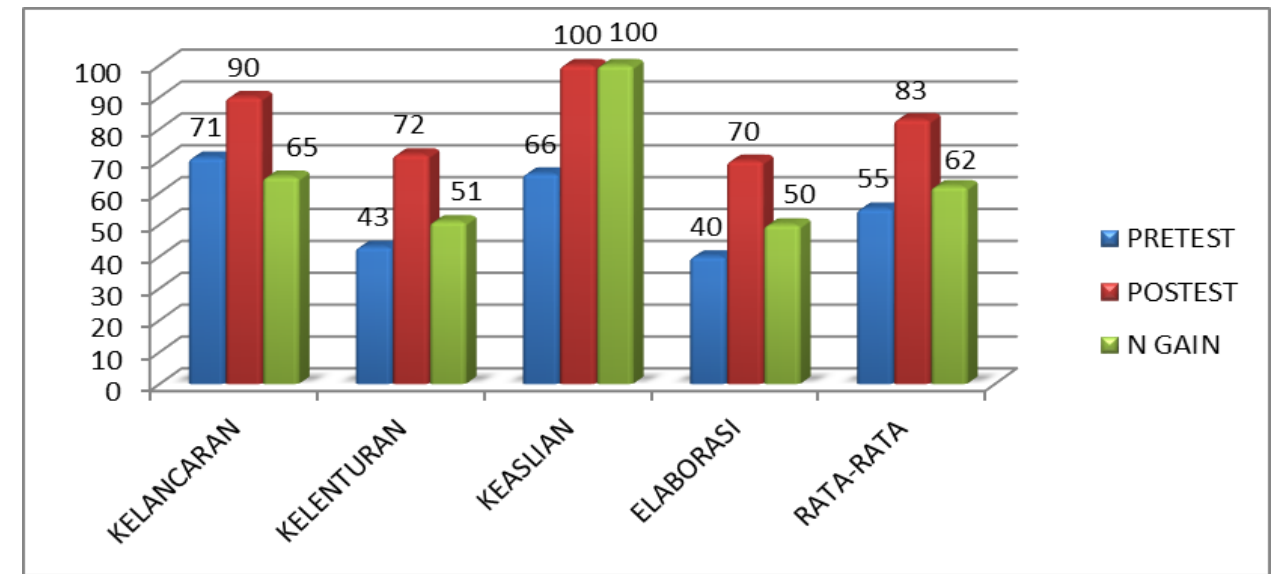

Gambar 1. Grafik Persentase N-Gain Kemampuan Berpikir Kreatif Kelas Eksperimen

Gambar 2 menunjukan persentase N-Gain sebesar 65\%, 51\%, dan 50\% dengan kriteria sedang, sedangkan pada indikator keaslian menunjukan persentase sebesar $100 \%$ dengan kriteria tinggi, serta diperoleh persentase rata-rata N-Gain untuk pretest sebesar $62 \%$ dengan kategori sedang dan rata-rata $\mathrm{N}$-gain posttest sebesar $83 \%$ dengan kriteria tinggi, sedangkan N-Gain total diperoleh persentase sebesar $62 \%$ dengan kriteria sedang. Berikut ini untuk membandingkan persentase per indikator disajikan data pada kelas kontrol pada Gambar 2.

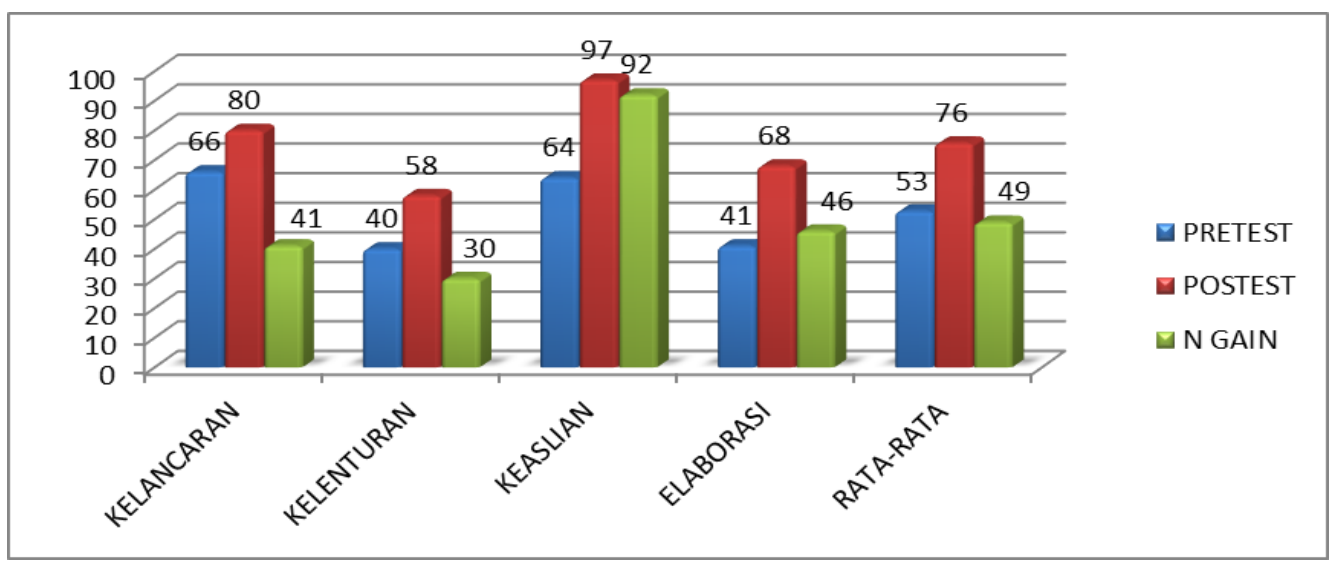

Gambar 2. Grafik Persentase N-Gain Kemampuan Berpikir Kreatif Kelas Kontrol

Persentase N-Gain pretest dan posttest per indikator kemampuan berpikir kreatif menunjukan persentase N-Gain sebesar 41\%, 30\%, 46\%, dan 53\% dengan kriteria sedang, sedangkan pada indikator keaslian menunjukan persentase sebesar $92 \%$ dengan kriteria tinggi untuk rata-rata $\mathrm{N}$-gain pretest pada kelas kontrol menunjukan persentse sebesar $53 \%$ dengan kritera sedang dan rata-rata $\mathrm{N}$-gain posttest sebesar $76 \%$ dengan kriteria tinggi, serta $\mathrm{N}$-gain total menunjukan persentase sebesar $49 \%$ dengan kategori sedang. 
Tabel 2. Rekapitulasi Rata-rata Nilai dan $\mathbf{N}$-gain Kemandirian Belajar Kelas Eksperimen dan Kontrol

\begin{tabular}{lcrrrr}
\hline & $\begin{array}{l}\text { Jumlah } \\
\text { Peserta } \\
\text { Didik }\end{array}$ & \multicolumn{2}{c}{ Nilai Rata-Rata } & N-Gain & Kriteria \\
& 29 & 48,66 & 79,39 & 0,62 & Sedang \\
\hline Eksperimen & 29 & 47,17 & 69,47 & 0,41 & Sedang \\
Kontrol & 29 & & & \\
\hline
\end{tabular}

Peneliti melakukan pretest kemandirian belajar sebanyak 20 pernyataan dalam bentuk angket, dimana kelas eksperimen mendapatkan nilai terendah 20dan nilai tertinggi 75,57, dengan jumlah peserta didik 29 medapatkan nilai rata-rata pretest sebesar 48,66. Sementara kelas kontrol mendapatkan nilai terendah 15 dan nilai tertinggi 73,33, dengan jumlah peserta didik 29 mendapatkan nilai rata-rata pretest sebesar 47,17 . Peningkatan kemandirian belajar dapat dilihat pada analisis per indikator sikap ilmiah pada kelas eksperimen dan kontrol ditunjukkan pada Gambar 3.

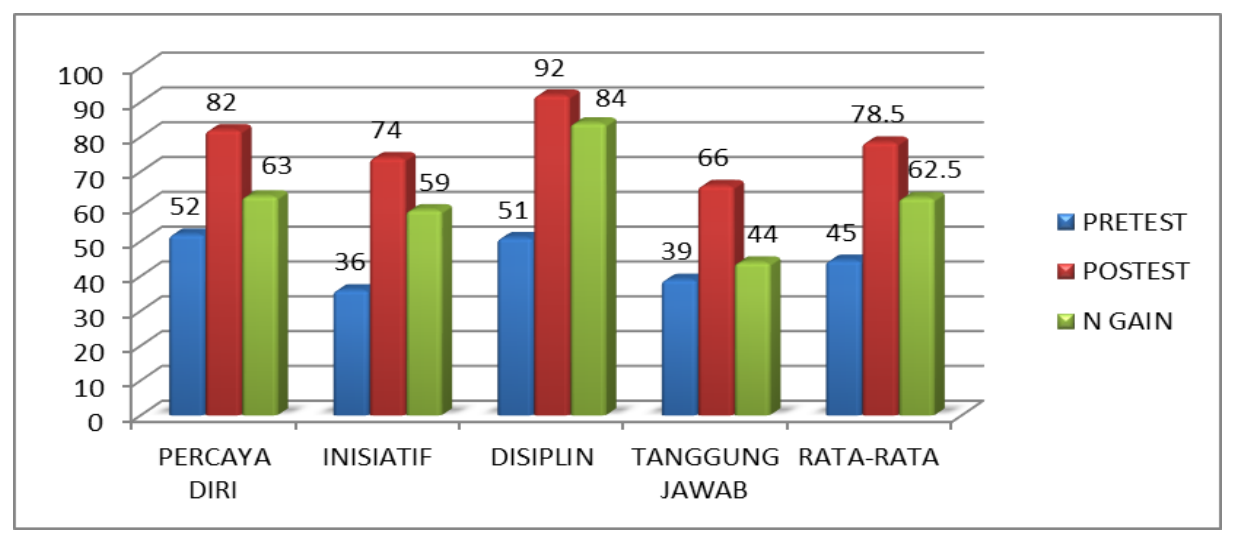

Gambar 3. Grafik N-gain Kemandirian Belajar Kelas Eksperimen

Persentase disetiap indikator kemandirian belajar kelas eksperimen dengan menerapkan model blended learning berbantu google classroom pada indikator percaya diri, inisiatif, dan tanggung jawab secara berurutan menunjukan nilai N-Gain sebesar $63 \%$, $59 \%$, dan $44 \%$, yang termasuk dalam kategori sedang dan pada indikator disiplin dengan $\mathrm{N}$-gain $84 \%$ termasuk dalam kategori tinggi , sedangkan skor rata-rata N-Gain pada pretest kelas eksperimen menunjukan skor sebesar $45 \%$ dan posttest sebesar $78,5 \%$, sedangkan skor total $\mathrm{N}$-gain diperoleh sebesar $62,5 \%$ degan kategori sedang. Berikut ini untuk membandingkan persentase $\mathrm{N}$-gain per indikator sikap ilmiah, disajikan data pada kelas kontrol seperti pada Gambar 4. 


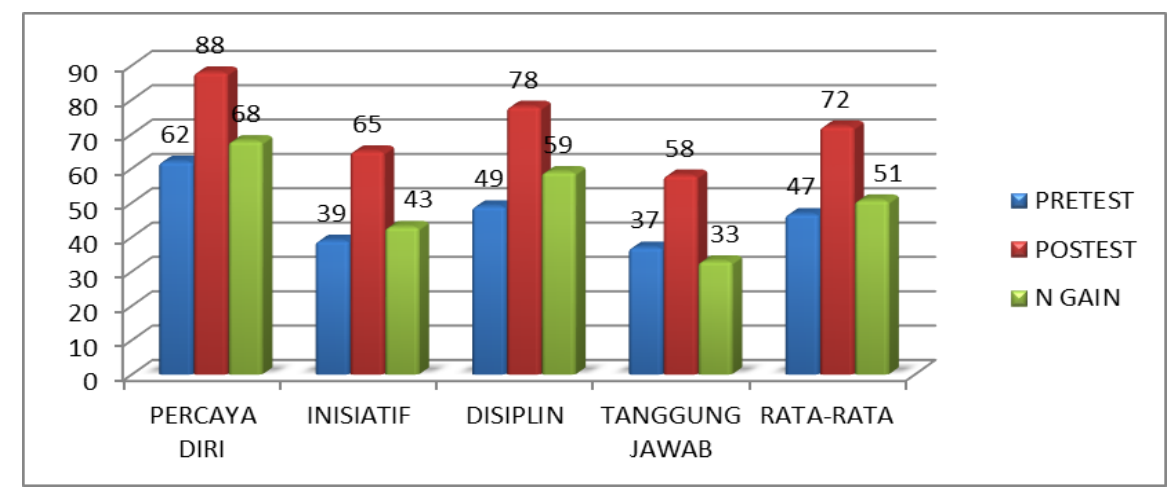

Gambar 4. Grafik N-gain Kemandirian Belajar Kelas Kontrol

Persentase disetiap indikator nilai sikap ilmiah kelas kontrol dengan menerapkan model blended learning berbantu google classroom pada indikator percaya diri, inisiatif, disiplin dan tanggung jawab secara berurutan menunjukan persentase N-Gain sebesar $68 \%$, 43\%, 59\%, dan 33\%, dengan kriteria sedang, semua indikator sikap ilmiah pada kelas kontrol menunjukan kriteria sedang. Serta diperoleh rata-rata persentase N-gain pretest kelas kontrol sebesar $47 \%$ dengan kriteria sedang, dan rata-rata persentase $\mathrm{N}$-gain posttest diperoleh sebesar $72 \%$ dengan kriteria tinggi. Sedangkan N-Gain total diperoleh sebesar $51 \%$ dengan kategori sedang. Hasil uji t-Independent ditunjukkan pada Tabel 3.

Tabel 3. Uji t- Independent

\begin{tabular}{ccc}
\hline $\mathbf{t}_{\text {hitung }}$ & $\mathbf{t}_{\text {tabel }}$ & Kesimpulan \\
\hline 3,85 & 2,00 & $\mathrm{H}_{1}$ diterima \\
\hline
\end{tabular}

Hipotesis ditentukan dengan melihat besarnya $t_{\text {hitung }}$ dan $t_{\text {tabel, }}$ jika $t_{\text {hitung }}>t_{\text {tabel }}$ maka $\mathrm{H}_{1}$ diterima, dan sebaliknya. Diketahui bahwa hasil perhitungan tersebut sebesar 3,85 ( $\mathrm{t}_{\text {hitung }}$ ) >2,00 ( $\left.\mathrm{t}_{\text {tabel }}\right)$, artinya model blended learning berbantu google classroom berpengaruh terhadap peningkatan kemandirian belajar.

Berdasarkan hasil analisis data yang telah dilakukan menjelaskan bahwa data awal kemampuan berpikir kreatif peserta didik pada kelass eksperimen dan kelas kontrol tidak terlalu jauh, hal ini menunjukkan bahwa kedua kelas tersebut belum menguasai materi keanekaragaman hayati. Setelah menggunakan model pembelajaran blended learning dalam proses pembelajaran peserta didik diberikan tes akhir yang hasilnya menunjukkan perbedaan rata-rata posttest anatara kelas eksperimen dan kelas kontrol.

Kelas eksperimen mendapatkan nilai rata-rata posttest sebesar 79,39 dengan nilai $N$-gain 0,62, sementara kelas kontrol mendapatkan nilai rata-rata posttest sebesar 69,47 dengan nilai $N$-gain 0,41 . Ini membuktikan jika perolehan hasil kemampuan berpikir kreatif kelas eksperimen lebih tinggi dibandingkan kelas kontrol. Peningkatan kemampuan berpikir kreatif pada peserta didik kelas eksperimen dikarenakan adanya pengaruh model pembelajaran blended learning. Sementara kelas kontrol hanya menerapkan intruction 
dengan menerapkan metode ceramah, tanya jawab dan diskusi saja. Penelitian yang dilakukan oleh Nuraini, dkk (Nuraini et al., 2018) menyatakan bahwa pembelajaran dengan menggunakan model pembelajaran blended learning ternyata dapat meningkatkan motivasi serta hasil belajar peserta didik, dikarenakan pembelajaran dengan menggunakan model pembelajaran blended learning menimbulkan ketertarikan peserta didik untuk belajar dan akan berpengaruh terhadap hasil belajarnya.

Penerapan model pembelajaran blended learning dapat digunakan sebagai strategi pengorganisasian pembelajaran, penyampaian pembelajaran serta kualitas pengajaran, dikarenakan blended learning bisa untuk mengakomodasi perkembangan teknologi yang semakin pesat diera 21 tanpa harus meninggalkan pembelajaran tatap muka (Maryam, 2018). Materi dalam pembelajaran biologi tidak terlepas dari teori yang membuat peserta didik merasa bosan, dengan memanfaatkan internet peserta didik dapat mengakses materi yang mudah dipahami seperti video, maupun gambar dengan leluasa. Berikut ditemukan beberapa penulisan yang berkaitan dengan penelitian ini. Hasil penelitian Fitriasari et al., (2018), menunjukkan bahwa terdapatnya pengaruh yang signifikan model blended learning berbasis google classroom terhadap peningkatan hasil belajar mahapeserta didik pendidikan fisika. Blended learning dapat digunakan sebagai salah satu variasi dalam pembelajaran matematika, karena dengan menggunakan strategi pembelajaran ini mahapeserta didik dapat berpartisipasi aktif dalam pembelajaran dan juga mampu meningkatkan kemampuan berpikir kreatif (Setyoko, 2018a). Peningkatan kemandirian belajar mahapeserta didik yang mendapatkan blended learning tidak lebih baik daripada mahapeserta didik yang mendapatkan pembelajaran konvensional (Fitriasari et al., 2018), namun blended learning berpotensi untuk meningkatkan kemandirian belajar mahapeserta didik.

Berdasarkan hasil analisis rekapitulasi nilai perindikator antara kelas eksperimen dengan kelas kontrol dapat disimpulkan bahwa nilai angket kemandirian belajar peserta didik pada materi sisem sirkulasi untuk kelas eksperimen lebih baik jika dibandingkan dengan kelas kontrol. Artinya pembelajaran dengan menggunakan model blended learning dapat meningkatkan kemandirian belajar peserta didik. Dengan dilaksanakannya pertemuan tatap muka dan online dapat meningkatkan kemandirian belajar pada peserta didik, hal ini sesuai dengan kelebihan model blended learning dimana memungkinkan peserta didik untuk belajar dimana pun dan kapan pun serta peserta didik dapat belajar sesuai dengan karakteristik dan langkahnya sendiri karena pembelajaran berbasis internet membuat pembelajaran menjadi efisien. 


\section{SIMPULAN}

Kesimpulan dari penelitian ini adalah terdapat pengaruh model pembelajaran blended learning berbantu google classroom terhadap kemampuan berpikir kreatif peserta didik pada kelas eksperimen ditunjukan dengan nilai $\mathrm{N}$-gain dalam kategori sedang. Terdapat pengaruh model pembelajaran blended learning berbantu google classroom terhadap kemandirian belajar peserta didik ditunjukan dengan hasil analisis data $\mathrm{N}$-gain sebesar dalam kategori sedang sehingga model ini dapat direkomendasikan untuk diterapkan dalam pembelajaran.

\section{DAFTAR PUSTAKA}

Anggoro, B. S. 2015a. Pengembangan Modul Matematika dengan Strategi Problem Solvin Guntuk Mengukur Tingkat Kemampuan Berpikir Kreatif Matematis Siswa. Al-Jabar: Jurnal Pendidikan Matematika, 6(2), 121-130. Dalam http://www.ejournal.radenintan.ac.id/index.php/al-jabar/article/viewFile/25/436 diakses pada 19 september 2019

Anggoro, B. S. 2015b. Pengembangan Modul Matematika dengan Strategi Problem Solving untuk Mengukur Tingkat Kemampuan Berfikir Kreatif Matematika Siswa. Jurnal Al-Jabarar, $6(2), \quad 121-129 . \quad$ Dalam http://moraref.kemenag.go.id/documents/article/97406410605918505/download diakses pada 29 september 2019

Arnyana, I. B. P. 2019. Pembelajaran Sains di Era Revolusi Industri 4.0. Prosiding Seminar Nasional MIPA, $8 . \quad$ Dalam https://ejournal.undiksha.ac.id/index.php/semnasmipa/article/view/16716 diakses pada 29 september 2019

Budiman, H. 2017. Peran Teknologi Informasi dan Komunikasi dalam Pendidikan. AlTadzkiyyah: Jurnal Pendidikan Islam, 8(1), 31-43. Dalam http://ejournal.radenintan.ac.id/index.php/tadzkiyyah/article/download/2095/1584 diakses pada 29 september 2019

Damanhuri, A., Mujahidin, E., \& Hafidhuddin, D. 2013. Inovasi Pengelolaan Pesantren dalam Menghadapi Persaingan di Era Globalisasi. Ta'dibuna: Jurnal Pendidikan Is lam, 2(1), 17-37. Dalam http://ejournal.uikabogor.ac.id/index.php/TADIBUNA/article/view/547. diakses pada 3 oktober 2019

Denizulaiha, D. 2018. Peran Guru Sekolah Dasar dalam Pembelajaran di Era Teknologi Digital. Prosiding seminar nasional program pascasarjana Universitas PGRI Palembang. Dalam https://jurnal.univpgripalembang.ac.id/index.php/Prosidingpps/article/view/1887. diakses pada 19 september 2019

Fitriasari, P., Tanzimah, T., \& Sari, N. 2018. Kemandirian Belajar Mahasiswa Melalui Blended Learning pada Mata Kuliah Metode Numerik. Jurnal Elemen, 4(1), 1-8. Dalam http://e-journal.hamzanwadi.ac.id/index.php/jel/article/view/439 diakses pada 18 september 2019 
Gani, A. G. 2018. E-Learning Sebagai Peran Teknologi Informasi dalam Modernisasi Pendidikan. Jurnal Sistem Informasi Universitas Suryadarma, 3(1). Dalam https://journal.universitassuryadarma.ac.id/index.php/jsi/article/view/52 diakses pada 3 oktober 2019

Guswiyata, S., Anggoro, B. S., \& Haka, N. B. 2018. Analisis Keterampilan Proses Sains dan Sikap Ilmiah Peserta Didik Kelas XI Mata Pelajaran Biologi Di SMA Al-Azhar 3 Bandar Lampung. Jurnal Biosfer, 9(2), 249-258. Dalam http://ejournal.radenintan.ac.id/index.php/biosfer/article/view/4025 diakses pada 16 september 2019

Imawanty, I., \& Fransiska, A. B. 2019. Guru Bimbingan dan Konseling Berkualitas di Era Revolusi 4.0: Pembelajar, Kompeten, dan up to Date. Prosiding Seminar Nasional Pendidikan FKIP, 2, 147-153. Dalam http://jurnal.untirta.ac.id/index.php/psnp/article/download/5726/4108 diakses pada 19 september 2019

Juniati, N. W., \& Widiana, I. W. 2017. Penerapan Model Pembelajaran Inkuiri Untuk Meningkatkan Hasil Belajar IPA. Jurnal IImiah Sekolah Dasar, 1(1), 20-29. Dalam https://ejournal.undiksha.ac.id/index.php/JISD/article/view/10126 diakses pada 16 september 2019

Karyawati, A. T. 2012. Tinjauan Umum Tingkah Laku Makan pada Hewan Primata. Jurnal Penelitian Sains, 15(1). Dalam https://media.neliti.com/media/publications/168380-IDtinjauan-umum-tingkah-laku-makan-pada-he.pdf diakses pada 16 september 2019

Kurniasih, N., \& Haka, N. B. 2017. Penggunaan Tes Diagnostik Two-Tier Multiple Choice untuk Menganalisis Miskonsepsi Siwa Kelas X Pada Materi Archaebacteria dan Eubacteria. Jurnal Biosfer, 8(1), 114-127. Dalam http://ejournal.radenintan.ac.id/index.php/biosfer/article/view/1270 diakses pada 4 oktober 2019

Listiana, L. 2013. Pemberdayaan Keterampilan Berpikir dalam Pembelajaran Biologi melalui Model Kooperatif Tipe Gl (Group Investigation) dan TTW (Think, Talk, Write). Proceeding Biology Education Conference: Biology, Science, Enviromental, and Learning, 10. Dalam https://jurnal.uns.ac.id/prosbi/article/view/6442/5822 diakses pada 17 januari 2020

Maryam, I. 2018. Pengaruh Blended Learning Berbantuan Microsoft Mathematic Terhadap Kemampuan Berpikir Kreatif. Jurnal Pendidikan Surya Edukasi (JPSE), 4(2), 23-34. Dalam $\quad$ http://ejournal.umpwr.ac.id/index.php/surya/article/download/5340/4879 diakses pada 19 september 2019

Mayasari, F. 2016. Upaya Meningkatkan Kemandirian Belajar Siswa Melalui Penerapan Blended Learning Berbantuan Quipper School. Jurnal Tata Arta, 2(3), 159. Dalam http://jurnal.fkip.uns.ac.id/index.php/tataarta/article/view/11480 diakses pada 19 september 2019

Nuraini, S., Distrik, I. W., \& Suana, W. 2018. Pengembangan Lembar Kerja Siswa Blended Learning Berorientasi Higher Order Thinking Skilss. PASCAL (Journal of Physics and Science Learning), 2(1), 69-77. http://jurnal.untirta.ac.id/index.php/Gravity/article/view/46-49 diakses pada 19 september 2019 
Nurjanah, S. 2015. Peranan Manajemen Inovasi dalam Meningkatkan Kinerja Organisasi Pendidikan. Conference In Business, Accounting, And Management (CBAM), 2, 2733. Dalam http://jurnal.unissula.ac.id/index.php/cbam/article/view/288/235 diakses pada 19 september 2019

Pardede, T. 2011. Pemanfaatan E-Learning Sebagai Media Pembelajaran pada Pendidikan Tinggi Jarak Jauh. Dalam http://repository.ut.ac.id/2511/ diakses pada 19 september 2019

Priana, R. Y. S. 2017. Pemanfaatan Vlog Sebagai Media Pembelajaran Teritegrasi Tekhnologi Informasi. Prosiding Seminar Nasional Pendidikan FKIP, 1. Dalam http://jurnal.untirta.ac.id/index.php/psnp/article/viewFile/313-316/1719 diakses pada 17 januari 2020

Rakhmawati, D. 2017. Konselor Sekolah Abad 21: Tantangan dan Peluang. Jurnal Konseling GUSJIGANG, 3(1). Dalam https://jurnal.umk.ac.id/index.php/gusjigang/article/download/1067/1065 diakses pada 19 september 2019

Ramdhani, M. A. 2017. Lingkungan Pendidikan dalam Implementasi Pendidikan Karakter. Jurnal Pendidikan UNIGA, 8(1), 28-37. Dalam https://journal.uniga.ac.id/index.php/JP/article/viewFile/69/70 diakses pada 19 september 2019

Ridwan, A. E. 2014. Pendidikan IPS dalam Membentuk SDM beradab. Jurnal Pendidikan IImu Sosial, 23(1). Dalam https://ejournal.upi.edu/index.php/ipis/article/viewFile/2060/1451 diakses pada 19 september 2019

Rodiawati, H., \& Komarudin, K. 2018. Pengembangan E-Learning Melalui Modul Interaktif Berbasis Learning Content Development System. Jurnal Tatsqif, 16(2), 172-185. Dalam https://journal.uinmataram.ac.id/index.php/tatsqif/article/view/190 diakses pada 19 september 2019

Santono, H. 2019. Implementasi Sistem Informasi Pembayaran SPP Berbasis Web, Barcode, dan SMS Gateway. Prosiding Seminar Nasional Teknologi Informasi Dan Komunikasi (SENATIK), 2, 255-260. Dalam https://ejournal.nusamandiri.ac.id/index.php/inti/article/view/1125 diakses pada 19 september 2019

Setyoko. 2018a. Implementasi Pembelajaran Blended Learning Berbasis Media Google Classrom Terhadap Hasil Belajar Mahasiswa Pendidikan Fisika. Jurnal Pendidikan Fisika Dan Sains, $1(2), \quad 9 . \quad$ Dalam https://www.ejurnalunsam.id/index.php/JPFS/article/view/870 diakses pada 17 januari 2020

Setyoko, S. 2018b. Implementasi Pembelajaran Blended Learning Berbasis Media Google Classrom Terhadap Hasil Belajar Mahasiswa Pendidikan Fisika. Jurnal Pendidikan Fisika Dan Sains, 1(2), 5-10. Dalam https://libraryeproceeding.telkomuniversity.ac.id/index.php/management/article/view/6 $\underline{185}$ diakses pada 16 september 2019 
Siregar, R. K. D., \& Fitriawan, R. A. 2018. Analisis Kualitas Website Ruangguru. com Menggunakan Metode Webqual 4.0 Dan Ipa (importance Performance Analysis). eProceedings of Management, 5(1). Dalam http://ejournal.unipma.ac.id/index.php/JF/article/view/403 diakses pada 19 september 2019

Sudarisman, S. 2015. Memahami Hakikat dan Karakteristik Pembelajaran Biologi dalam Upaya Menjawab Tantangan Abad 21 Serta Optimalisasi Implementasi Kurikulum 2013. Florea: Jurnal Biologi Dan Pembelajarannya, 2(1). Dalam http://scholar.google.co.id/citations?user=ggl8GmQAAAAJ\&hl=id diakses pada 17 september 2019

Sudarsana, I. K. 2016. Peningkatan Mutu Pendidikan Luar Sekolah dalam Upaya Pembangunan Sumber Daya Manusia. Jurnal Penjaminan Mutu, 1(1), 1-14. Dalam http://jurnal.ulb.ac.id/index.php/informatika/article/view/219/204 diakses pada 19 september 2019

Suryadi, S. 2015. Peranan Perkembangan Teknologi Informasi dan Komunikasi dalam Kegiatan Pembelajaran dan Perkembangan Dunia Pendidikan. Jurnal Informatika, 3(3), 9-19. Dalam http://journal2.um.ac.id/index.php/itppips/article/view/221 diakses pada 17 september 2019

Syarif, E., Sumarmi, S., Fatchan, A., \& Astina, I. K. 2016. Integrasi Nilai Budaya Etnis Bugis Makassar Dalam Proses Pembelajaran Sebagai Salah Satu Strategi Menghadapi Era Masyarakat Ekonomi Asean (MEA). Jurnal Teori Dan Praksis Pembelajaran IPS, 1(1), 13-21. Dalam http://ejournal.radenintan.ac.id/index.php/aljabar/article/view/2028 diakses pada 16 september 2019

Weni, D. M., \& Isnani, G. 2016. Meningkatkan Hasil Belajar Siswa dengan Pengembangan Media Pembelajaran E-Learning Berbasis Blog. JPBM (Jurnal Pendidikan Bisnis Dan Manajemen), 2(2), 114-122. Dalam http://scholar.google.co.id/citations?user=gg|8GmQAAAAJ\&hl=id diakses pada 17 januari 2020

Zahara, N. Z. N. 2018. Evaluasi Pembelajaran Online Berbasis Web Sebagai Alat Ukur Hasil Belajar Siswa Pada Materi Dunia Tumbuhan Kelas X Man Model Banda Aceh. $\begin{array}{lll}\text { Prosiding Biotik, 2(1). Dalam } & \end{array}$ http://sinta.ristekbrin.go.id/affiliations/detail?page=94\&id=3519\&view=documents diakses pada 17 januari 2020 